\title{
Antibacterial Activity of Syrian Capparis spinosa. (Capparidaceae) Leaves and Roots
}

\author{
Hala Deeb \\ Al Hawash Private University, Hims, Syria
}

\begin{abstract}
The ethanolic extract of Capparis Spinosa. leaves and Roots were tested for their antibacterial activity against four species of bacteria, Bacillus subtilis, Escherichia coli, Klebsiella sp., Staphylococcus aureus using disc diffusion technique. The extract concentrations of ethanolic leaf and root extracts used were 0 (control), 125, 250, 500 and $1000 \mathrm{ppm}$ in triplicates along with standard antibiotic, Ciprofloxacine $(5 \mu \mathrm{g})$, Gentamycine $(10 \mu \mathrm{g})$. Comparatively, ethanolic root extracts showed higher activity than ethanolic leaf extracts. The results showed that In $1000 \mathrm{ppm}$ ethanolic root extract, a maximum of $3.2 \mathrm{~cm}$ ZI was observed against Staphylococcus aureus followed by 2.3 against Escherichia coli. The maximum ZI of $2.8 \mathrm{~cm}$ was recorded in $1000 \mathrm{ppm}$ extract of leaves against Staphylococcus aureus followed by $2.0 \mathrm{~cm}$ against Escherichia coli.
\end{abstract}

Keywords: Capparis Spinosa, ethanolic extract, leaves and Roots, antibacterial activity.

DOI: $10.7176 / \mathrm{JBAH} / 9-16-05$

Publication date: August $31^{\text {st }} 2019$

\section{Introduction}

Capparis Spinosa L. belonging to the family, Capparidaceae is a thorny much branched shrub traditionally used for the treatment of jaundice, inflammation and dysentery (Indian Medicinal Plants, 1999; Matthew, 1991). Various parts of Capparis Spinosa has been reported to possess anti-inflammatory and analgesic actitivies (Chaudhari et al., 2004) and, hepatoprotective activity (Satyanarayana et al., 2009); ethanolic leaf extracts also showed significant in vitro free radical scavenging activity (Thirumalaikumaran and Reddy, 2011); stem extracts of Capparis Spinosa are reported to possess antimicrobial and anti-inflammatory activity (Satyanarayana et al., 2010). There are very scientific reports available with regard to the biological activities of Capparis Spinosa, the antibacterial activity of leaf and root extracts is scanty. Hence, the present study has been aimed to study the antibacterial activity of ethanolic extracts of leaves and roots of Syrian Capparis Spinosa against four selective bacteria.

\section{Materials and Methods}

The leaves and roots of Syrian Capparis Spinosa L. (Fig. 1) belonging to the Family, Capparidaceae were collected in April and the identification was confirmed using standard local floras (Gamble and Fischer, 1957; Matthews, 1983). The cold extraction procedure was used for extracting leaves with solvents as per the procedure given below (Prakash and Karmegam, 2012). The leaves and roots of Syrian Capparis Spinosa collected were individually washed with tap water, blotted with filter paper and spread over news paper for air drying under shade. After complete dryness, the leaves and roots were powdered using a mixer grinder.

A known quantity of the powder $(100 \mathrm{~g})$ of each plant was taken in a $250 \mathrm{ml}$ conical flask and added with $100-200 \mathrm{ml}$ of ethanol individually for leaves and roots. The solvent-powder mixtures were kept at room temperature for $48 \mathrm{hrs}$ and rapidly stirred using glass rod every $8 \mathrm{hrs}$. After $48 \mathrm{hrs}$, the extract of each plant part was filtered to exclude the powder/particles. Then each filtrate was kept in beaker on a water bath at $45^{\circ} \mathrm{C}$ until the solvent gets evaporated. A greasy final material (crude extract) obtained for the leaves and roots was transferred to screw cap tubes and stored under refrigerated condition till use.

By using digital electronic balance, $200 \mathrm{mg}$ of each crude extract was carefully taken in a standard measuring flask and $5 \mathrm{ml}$ of ethanol was added to dissolve the extract and 1-2 drops of emulsifier (Triton-X100) was added to completely dissolve the extract. Then it was made up to $200 \mathrm{ml}$ by adding distilled water. This forms the stock solution of $1000 \mathrm{ppm}$ (i.e., $1 \mathrm{mg} / \mathrm{ml}$ ), from which different concentrations of test solutions, 125 , 250,500 and $1000 \mathrm{ppm}$ were prepared and used for antibacterial assay. Disc diffusion method of antibacterial assay was used to test the sensitivity of selected test organisms to the ethanolic extracts.

Each extract $(100 \mu \mathrm{l})$ was applied to filter paper discs measuring and allowed to dry before being placed on the agar plate.

The test bacteria, Bacillus subtilis, Escherichia coli, Klebsiella sp., and Staphylococcus aureus maintained in the Laboratory of Department of Microbiology, in Damascus University. The Petri plates of $100 \mathrm{~mm}$ diameter with nutrient agar media were swabbed with broth culture of the test bacteria in separate plates by using sterile swab. Over this, prepared antimicrobial discs were placed under aseptic conditions. Three discs of each extract were placed in triangle. Ciprofloxacine $(5 \mu \mathrm{g})$, Gentamycine $(10 \mu \mathrm{g})$ were used as standard antibiotic. Also the discs without plant extract were also maintained as control. The plates were then incubated at $37^{\circ} \mathrm{C}$ for $24 \mathrm{hrs}$ 
and the zone of inhibition (ZI) was measured in diameter $(\mathrm{cm})$ around the discs and recorded. The assays were performed with three replicates. From the results, activity index was calculated by comparing the ZI of leaf extracts with standard antibiotic.

\section{Results and Discussion}

Syrian Capparis Spinosa is a genus distributed in many parts of the world with its many species showing varieties of medicinal properties. The medicinal uses of Capparis Spinosa are well known and the supporting scientific data available is very scanty. The present study reports the antibacterial activity of leaf and roots extracts against four different bacteria. The standard antibiotic, Ciprofloxacine $(5 \mu \mathrm{g})$ showed a range of 3.5-3.7 $\mathrm{cm}$ zone against the test bacteria, Gentamycine $(10 \mu \mathrm{g})$ showed a range of 3.6- $4.0 \mathrm{~cm}$ zone against the test bacteria. The antibacterial activity of leaf and roots extracts of Syrian Capparis Spinosa measured in terms of zone of inhibition (ZI) showed variations among different concentrations of extracts and among different bacterial species tested (Tables 1 and 2). Only minimum activity was found in $125 \mathrm{ppm}$ and $250 \mathrm{ppm}$ concentrations of ethanolic leaf extracts against test bacteria. The leaf extract of $500 \mathrm{ppm}$ showed antibacterial activity against all bacteria tested excepting Klebsiella sp. which ranged from 0.4 to $1.1 \mathrm{~cm} \mathrm{ZI}$. In $1000 \mathrm{ppm}$ leaf extract, a maximum of $2.8 \mathrm{~cm}$ ZI was observed against Staphylococcus aureus followed by 2.0 against Escherichia coli. The least ZI of $0.9 \mathrm{~cm}$ was found in $1000 \mathrm{ppm}$ leaf extract against Bacillus subtilis, and Klebsiella (Table 1).

In comparison, the roots extracts showed higher ZI against tested bacteria than ethanolic leaf extracts of Capparis Spinosa. The maximum ZI of 3-3.2 cm was recorded in $1000 \mathrm{ppm}$ ethanolic root extract against Staphylococcus aureus followed by $2.3 \mathrm{~cm}$ against Escherichia coli (Table 2).

In the present study, the leaves and roots were subjected to antimicrobial activity against selective bacteria in which the results revealed that the ethanolic root extracts had good antibacterial activity.

In conclusion, the ethanolic leaf and root extracts of Syrian Capparis Spinosa. showed concentration dependent antibacterial activity. The extracts showed maximum activity in the highest concentration of 1000 ppm used in the present study.

Ethanolic root extracts of Syrian Capparis Spinosa showed higher activity than ethanolic leaf extracts. The maximum ZI of $3.2 \mathrm{~cm}$ was recorded in $1000 \mathrm{ppm}$ ethanolic roots extract against Staphylococcus aureus followed by $2.3 \mathrm{~cm}$ against Escherichia coli.

\section{References}

1. Indian Medicinal Plants, 1999. Vol. 1. Orient Longman Publishers, CSIR, New Delhi. 348p.

2. Chaudhari, S.R., Chavan, M.J., Gaud, R.S., 2004. Phytochemical and pharmacological research on the roots of Capparis sepiaria. Ind. J. Pharmaceut. Sci. 66, 454-457.

3. Satyanarayana, T., Kshama Devi, Mathews, A. A., 2009. Hepatoprotective activity of Capparis sepiaria stem against carbon tetrachloride-induced hepatotoxicty in rats. J. Pharmaceut. Res. Health Care. 1(1), 34-35.

4. Thirumalaikumaran, R., Reddy, C.U., 2011. Evaluation of hepatoprotective activity of Capparis sepiaria leaves. Int. J. Biomed. Res. 2(3), 204-212.

5. Satyanarayana, T., Mathews, A. A., Anjana Male, Ch. K. V. L. S. N., Surendra, G., 2010. Screening of antiinflammatory and antimicrobial activities of stem extract of Capparis sepiaria Linn. Res. J. Pharmaceut. Biol. Chem. Sci. 1(3), 330-336.

6. Prakash, M., Karmegam, N., 2012. In-vitro antibacterial activity of certain plant extracts against plant disease causing bacteria isolated from citrus plant. Int. J. Curr. Microbiol. App. Sci. 1(1), 1-11.

7. Mahboubi, M., Mahboubi, A., 2014. Antimicrobial activity of Capparis spinosa as its usages in traditional medicine. Kerba Polonica. 60(1), 1-10. 


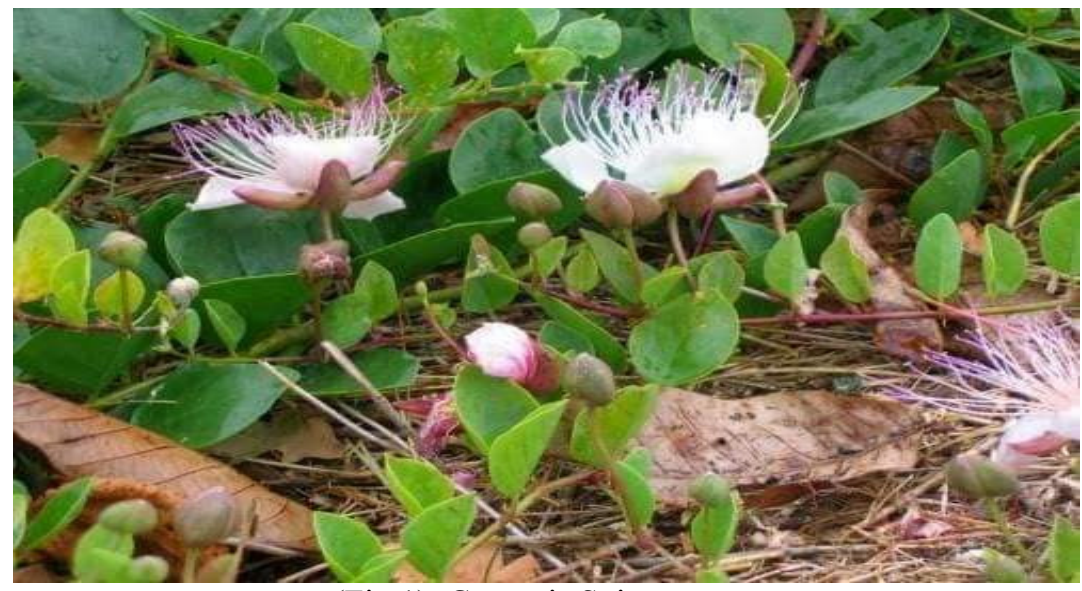

(Fig.1): Capparis Spinosa.

Table 1: antibacterial effect of leaves of Capparis Spinosa.

\begin{tabular}{|c|c|c|c|c|c|c|c|}
\hline \multirow{2}{*}{ Bacteria tested } & \multicolumn{7}{|c|}{ Zone of inhibition $(\mathrm{cm})^{\#}$} \\
\hline & Std.1 & Std.2 & 0 ppm $^{\text {\$ }}$ & 125 ppm & 250 ppm & 500 ppm & 1000 ppm \\
\hline Bacillus subtilis & 3.7 & - & - & - & - & 0.4 & 0.9 \\
\hline Escherichia coli & 3.4 & $3.6-3.9$ & - & - & 0.4 & 1.0 & 2.0 \\
\hline Klebsiella sp & 3.1 & - & - & - & - & $\mathbf{0}$ & 0.9 \\
\hline Staphylococcus aureus & $3.5-3.7$ & 4.0 & - & 0.2 & 0.4 & 1.1 & 2.8 \\
\hline
\end{tabular}

Table 2: antibacterial effect of root of Capparis Spinosa

\begin{tabular}{|c|c|c|c|c|c|c|c|}
\hline \multirow{2}{*}{ Bacteria tested } & \multicolumn{7}{|c|}{ Zone of inhibition $(\mathrm{cm})^{\#}$} \\
\hline & Std.1 & Std.2 & $0 \mathrm{ppm}^{\mathrm{s}}$ & 125 ppm & $250 \mathrm{ppm}$ & 500 ppm & $1000 \mathrm{ppm}$ \\
\hline Bacillus subtilis & 3.7 & - & - & - & - & 0.4 & 1.1 \\
\hline Escherichia coli & 3.4 & $3.6-3.9$ & - & - & 0.4 & 1.3 & 2.3 \\
\hline Klebsiella sp & 3.1 & - & - & - & - & 0.1 & 0.4 \\
\hline Staphylococcus aureus & 3.5-3.7 & 4.0 & - & 0.2 & 1.1 & 2.7 & 3.2 \\
\hline
\end{tabular}

\# - Values are mean of three replicates; \$ - Control (without extract); Std.1 - Standard antibiotic, Chloramphenicol $(30 \mu \mathrm{g}) ;$ Std. 2 - Standard antibiotic, Gentamycine $(10 \mu \mathrm{g})$; AD - Around the disc. 